\title{
An Empirical Study of Online Discussion Forums by Library and Information Science Postgraduate Students using Technology Acceptance Model 3
}

\author{
Airen Adetimirin \\ Department of Library, Archival and Information Studies, \\ University of Ibadan, Ibadan, Nigeria
}

\author{
aeadetimirin@gmail.com; ae.adetimirin@mail.ui.edu.ng
}

\begin{abstract}
E-learning is an important trend globally that is believed to enhance the acquisition of knowledge by students within and outside the classroom to improve their academic pursuit. The Online Discussion Forum (ODF) is one of the tools that are used for e-learning in Nigerian universities. It facilitates interaction among postgraduate students as they can communicate and share information sources with one another to promote learning. However, the optimum use of this forum is determined by anchor factors in TAM 3 such as computer self-efficacy, perceptions of external control, computer anxiety and computer playfulness. A conceptual model based on TAM 3 was proposed and empirically tested. Using a survey research design and an online questionnaire for 121 Library and Information Science (LIS) postgraduate students, the paper demonstrated that computer self-efficacy, perceptions of external control, computer anxiety and computer playfulness have significant influence on the use of ODF. The paper therefore proposes that Online Discussion Forums should be encouraged for learning in postgraduate education.
\end{abstract}

Keywords: Online discussion, E-learning, TAM 3, Postgraduate students, Nigeria

\section{Introduction}

The Online Discussion Forum (ODF) is one of the learning tools accepted globally in education. It is a forum in which instructors and students post to a threaded asynchronous discussion to provide a convenient mode of communication (Warren, 2008). Goode (2009) described an online discussion forum as one that provides opportunity for class material to be discussed, reviewed and reinforced. ODF is a forum in which students can write their responses and post them for all to see. The use of ODF has emerged as a common tool and an effective way of engaging students outside the classroom (Balaji \& Chakrabarti, 2010). It is an e-learning platform that allows stu-

Material published as part of this publication, either on-line or in print, is copyrighted by the Informing Science Institute. Permission to make digital or paper copy of part or all of these works for personal or classroom use is granted without fee provided that the copies are not made or distributed for profit or commercial advantage AND that copies 1) bear this notice in full and 2) give the full citation on the first page. It is permissible to abstract these works so long as credit is given. To copy in all other cases or to republish or to post on a server or to redistribute to lists requires specific permission and payment of a fee. Contact Publisher@InformingScience.org to request redistribution permission. dents to post messages to the discussion threads, interact and receive feedback from other students and instructor, activity that can foster a deeper understanding of the subject under study.

The benefits of ODF to postgraduate students are many: such as storage of students' written messages in the virtual space which can be retrieved and reviewed anytime (Balaji \& Chakrabarti, 
2010), it is less prone to be dominated by a single participant and allows students not interacting in their first language to be able to spend time constructing their contribution (Havard, Du, \& Olinzock 2005; Redmon \& Burger, 2004). ODFs are flexible, convenient and accessible for students (Warren, 2008), encourage social interaction (Blackmon, 2012) and intense participation in the learning process (Dorman \& Fraser, 2009). Other benefits of ODF are the challenges given to students to construct knowledge leading to higher cognitive outcomes (Lyons \& Evans, 2013; Pena-Shaff \& Nicholls, 2004; Struyven, Dochy, Janssens, \& Gielen, 2006). Bonk, Kim, and Zeng (2006) have predicted the future of blended learning as self determined, increased connectedness, community and collaboration and changed instructor roles and this is what is presently happening with the use of different tools for e-learning in university education.

The use of Online Discussion Forums by postgraduate students can be influenced by some factors such as cultural and self motivation (Al-adwan \& Smedley, 2012). The authors emphasized that teachers are the central focus in the Jordanian educational system and students in two Jordanian universities were found to hold the belief that learning is teacher centred. Other influencing factors include emotions, demographic factors, student's achievement, and online experience (Yukselturk, 2010).

There are a variety of models that have been used for different studies on learning, Social Presence model (SPM), Unified Theory of Use and Acceptance of Technology (UTUAT) and Technology Acceptance Model (TAM-1, 2, 3). The Social Presence Model (SPM) is based on programmatic research in social presence (Whiteside, 2007). It involves five elements that can help lecturers and students to improve the learning experience: Affective Association, Community Cohesion, Interaction Intensity, Knowledge and Experience, and Instructor Investment. Affective Association (AA) addresses the emotional connections in a course as it examines emotion, humor, sarcasm, paralanguage, and self-disclosure. This involves the lecturer building a relationship with the students online. Community Cohesion (CC) represents the extent to which participants (lecturers and students) see the group as a community. CC has to do with the lecturer ensuring that there is social interaction with the students.

Interaction Intensity (II) refers to the level of interaction among participants. It measures the amount and quality of interaction in the online course and can be in the form of student-lecturer communication, student-student interaction, and student-content interaction. Knowledge and Experience (KE) involves the sharing of additional resources and experiences among the students as this improves comprehension and retention of information. This assists in the creation of a community of learners and continuous, high engagement in the course. Instructor Investment (IV) refers to the extent to which the instructor is an invested, active partner in the learning community. The lecturer must be involved in the learning activities of the students throughout the semester

UTUAT (Davis, Bagozzi, \& Warshaw, 1989) comprises ten components: Effort expectancy (EE), Performance expectancy (PE), Social influence (SI), Facilitating conditions (FC), Behavioral Intention (BI) and Use Behavior (UB). Others include: gender, age, experience and voluntariness to use. Effort expectancy is the degree of ease associated with the use of the system, while performance expectancy refers to the degree to which an individual believes that using the system will help him or her to attain gains in job performance. Social influence (SI) is the degree to which an individual perceives that others believe that he or her should use the new system, and facilitating conditions (FC) refers to the consumers' perception of the resources and support available to perform a behavior. Behavioral intention (BI) is the degree to which an individual has plans to use the system, while Use Behavior (UB) is the actual use of the system (Attuquayefio \& Addo, 2014; Venkatesh, Morris, Davis, \& Davis, 2003).

TAM is the most influential and common theory in information systems field (Lee, Kozar, \& Larsen, 2003) and has been used in many studies because it is easy and simple to understand 
(Aggorowati, Iriawan, Suhartono, \& Gautama, 2012; King \& He, 2006). It shows the influence on acceptance and use of a technology of a number of variables such as perceived usefulness (PU) and perceived ease of use (PEOU). TAM has been modified and expanded to TAM2 (Venkatesh 2000), UTUAT (Venkatesh et al., 2003) and recently TAM3 (Venkatesh \& Bala, 2008). TAM3 has additional variables such as anchor factors (computer self-efficacy, perception of external control, computer anxiety and computer playfulness), adjustment factors (perceived playfulness, objective usability), image, job relevance, output quality, result demonstrability, subjective norm, experience and voluntariness which could affect the perceived usefulness and perceived ease of use which may subsequently influence behavioural intention and finally use behavior (UB). However, the limitation of TAM as claimed Bagozzi (2007) is the failure to take into consideration the social processes of information system development and implementation to identify which technology is better and the social consequences of the use of information system. Aggorowati et al. (2012) concluded that the limitation of TAM which was derived from the analysis from 108 journals are limitation of sample size, homogeneity of samples, cultural dimension, the region of the samples, moderating variables, missing data and specification of researches.

This study focused on anchor factors in TAM3 which comprise computer self-efficacy, perception of external control, computer anxiety and computer playfulness. These factors are important in deciding to use any new information system (Venkatesh, 2000; Venkatesh, \& Bala, 2008). Computer self-efficacy can be defined as individuals' control beliefs regarding his or her personal ability to use a system. Compeau and Higgins (1995a, 1995b) explained computer self-efficacy as being the degree to which an individual believes that he or she has the ability to perform a specific task/job using the computer. Studies have revealed positive relationships between computer self-efficacy and computer usage (Gong, Xu, \& Yu, 2004; Saade \& Kira, 2009). The computer self-efficacy of postgraduate students may determine their use of ODF.

Perception of external control is a factor that might influence the use of ODFs by postgraduate students. Venkatesh et al., (2003) explained perception of external control as the degree to which an individual believes that organizational and technical resources exist to support the use of the system. A postgraduate student will use the ODF if it has current and relevant information that will improve learning outcomes.

Computer anxiety is also one of the anchor factors that can determine postgraduate students' use of ODF for learning. It refers to the degree of "an individual's apprehension, or even fear, when she/he is faced with the possibility of using computers" (Venkatesh, 2000). Postgraduate students who are anxious about using computers may have a negative behavior towards the use of ODF for learning and this may affect their learning outcome. However, those that are not afraid of using the computers will be able to access the ODF and interact with other students to improve their learning. Computer playfulness as a factor may determine the use of ODF by postgraduate students. It represents the intrinsic motivation associated with using any new system such as ODFs. Venkatesh (2000) explained that computer playfulness is the perception of pleasure and satisfaction from performing a task and it is system-independent. For this study, computer playfulness means the satisfaction derived from using ODF by postgraduate students.

Venkatesh (2000) suggested that anchors drive initial judgments of perceived ease of use. He theorized that even with increasing experience with the system, the role of computer self-efficacy and perceptions of external control will continue to be strong. However, the effects of computer playfulness and computer anxiety were theorized to diminish over time. Perceived ease of use has been theorized to be closely associated with individuals' self-efficacy beliefs and procedural knowledge, which requires hands-on experience and execution of skills (Davis et al., 1989; Davis $\&$ Venkatesh, 2004; Venkatesh, 2000). For postgraduate students to use ODF, they must believe that the ODF can be used for learning and that it only requires practice for it to be easy to use. Davis \& Venkatesh (2004) concluded further, that the determinants of perceived ease of use rep- 
resent several traits and emotions, such as computer self-efficacy, computer playfulness, and computer anxiety.

The determinants of perceived ease of use suggested by Venkatesh (2000) are primarily individual differences variables and general beliefs about computers and computer use, which will include ODF use. The perceptions of control (over a system), enjoyment or playfulness related to a system, and anxiety regarding the ability to use a system do not provide a basis for forming perceptions of instrumental benefits of using a system. Van der Heijden, (2004) reported that higher levels of computer playfulness or enjoyment from using a system do not mean that the system will help an individual to become more effective. It means that the satisfaction derived from using ODF does not indicate that postgraduate students will be more effective in retrieving information from ODF. Past studies (see for example, Davis \& Venkatesh, 2004; Venkatesh, 2000) have used TAM 3 to determine how an individual will use a technology. This study investigates the influence of anchor factors in TAM3 such as computer self-efficacy, perceptions of external control, computer anxiety and computer playfulness on the use of ODF by LIS postgraduate students.

\section{Objective of the Study}

This study aimed to investigate factors that determine the use of Online Discussion Forums by LIS postgraduate students in University of Ibadan with the following specific objectives to:

1. Determine the frequency of use of ODFs by the LIS postgraduate students

2. Examine the relationship between computer self-efficacy, perceptions of external control, computer anxiety, computer playfulness and use of ODFs by LIS postgraduate students.

\section{Theoretical Framework}

In information systems research, the user's attitude toward using and the actual usage of a technology are addressed in the technology acceptance model (Davis, 1989; Davis et al, 1989). TAM is a model developed specifically to explain how users accept computer technology $(\mathrm{Hu}, \mathrm{Chau}$, Sheng, \& Tam, 1999). It has been used as the theoretical basis for many empirical studies of user technology acceptance (Adams, Nelson, \& Todd, 1992; Davis, 1989; Davis et. al, 1989; Mathieson, 1991). Technology Acceptance Model 3 (TAM3) was the underlying theory for this study. Therefore, in this paper TAM 3 is used to study the acceptance of the online discussion forum (ODF) technology. The research presented here is guided by anchors factors such as computer self-efficacy, perceptions of external control, computer anxiety, and computer playfulness as it affects postgraduate students' use of ODF for learning.

TAM was developed to predict individual adoption and use of new ITs. It posits that individuals' behavioral intention to use an IT is determined by two beliefs: perceived usefulness, defined as the extent to which a person believes that using an IT will enhance his or her job performance and perceived ease of use, defined as the degree to which a person believes that using an IT will be free of effort. It further theorizes that the effect of external variables (e.g., design characteristics) on behavioral intention will be mediated by perceived usefulness and perceived ease of use. Over the last two decades, there has been substantial empirical support in favor of TAM (e.g., Adams et al., 1992; Agarwal \& Karahanna, 2000; Karahanna, Agarwal, \& Angst, 2006; Venkatesh et al., 2003; Venkatesh, Davis, \& Morris, 2007). However, in this study, use is not split into perceived usefulness and perceived ease of use but studied as one variable, 'use'.

Prior research employing TAM has focused on three broad areas. Firstly, some studies replicated TAM and focused on the psychometric aspects of TAM constructs (Adams et al., 1992; Hendrickson, Massey, \& Cronan, 1993). Secondly, other studies provided theoretical underpinning of the relative importance of TAM constructs; that is, perceived usefulness and perceived ease of use (e.g., Karahanna, Straub, \& Chervany, 1999). Finally, some studies extended TAM by adding 
additional constructs as determinants of TAM constructs (e.g., Karahanna \& Straub, 1999; Koufaris, 2002; Venkatesh, 2000; Venkatesh \& Davis, 2000).

Venkatesh (2000) developed a model of the determinants of perceived ease of use based on building on anchoring and adjustment framing of human decision making (TAM3). Venkatesh (2000)

argued that individuals will form early perceptions of the perceived ease of use of a system based on several anchors related to individuals' general beliefs regarding computers and computer use. The anchors suggested by Venkatesh (2000) are computer self-efficacy, perceptions of external control (or facilitating conditions), computer anxiety, and computer playfulness. Computer selfefficacy, computer anxiety, and computer playfulness represent individual differences, that is, general beliefs associated with computers and computer use.

Computer self-efficacy is the first factor that can affect use of ODFs and it refers to an individual's control beliefs regarding his or her personal ability to use a system. The second factor that influences the use of ODFs is perceptions of external control which relates to postgraduate student control beliefs regarding the availability of organizational resources and support structure to facilitate the use of ODF. Computer anxiety refers to the degree of "an individual's apprehension, or even fear, when she/he is faced with the possibility of using computers" (Venkatesh, 2000). Computer playfulness represents the intrinsic motivation associated with using any new system such as ODF. For this study, an investigation of how the four anchor factors computer selfefficacy, perceptions of external control (or facilitating conditions); computer anxiety and computer playfulness influence the use of ODF by LIS postgraduate students in the University of Ibadan was carried out.

\section{Hypotheses}

The research hypotheses based on Figure 1 (the diagram of the TAM 3 model in the context of the ODF) are:

$\mathrm{H}_{01}$ : Computer self-efficacy has no relationship with the use of ODFs by LIS postgraduate students.

$\mathrm{H}_{02}$ : Perceptions of external control have no relationship with use of ODFs by LIS postgraduate students.

$\mathrm{H}_{03}$ : Computer anxiety has no relationship with use of ODFs by LIS postgraduate students.

$\mathrm{H}_{04}$ : Computer playfulness has no relationship with use of ODFs by LIS postgraduate students

$\mathrm{H}_{05}$ : Computer self-efficacy, perceptions of external control, computer anxiety and computer playfulness jointly does not affect the use of ODFs by LIS postgraduate students. 


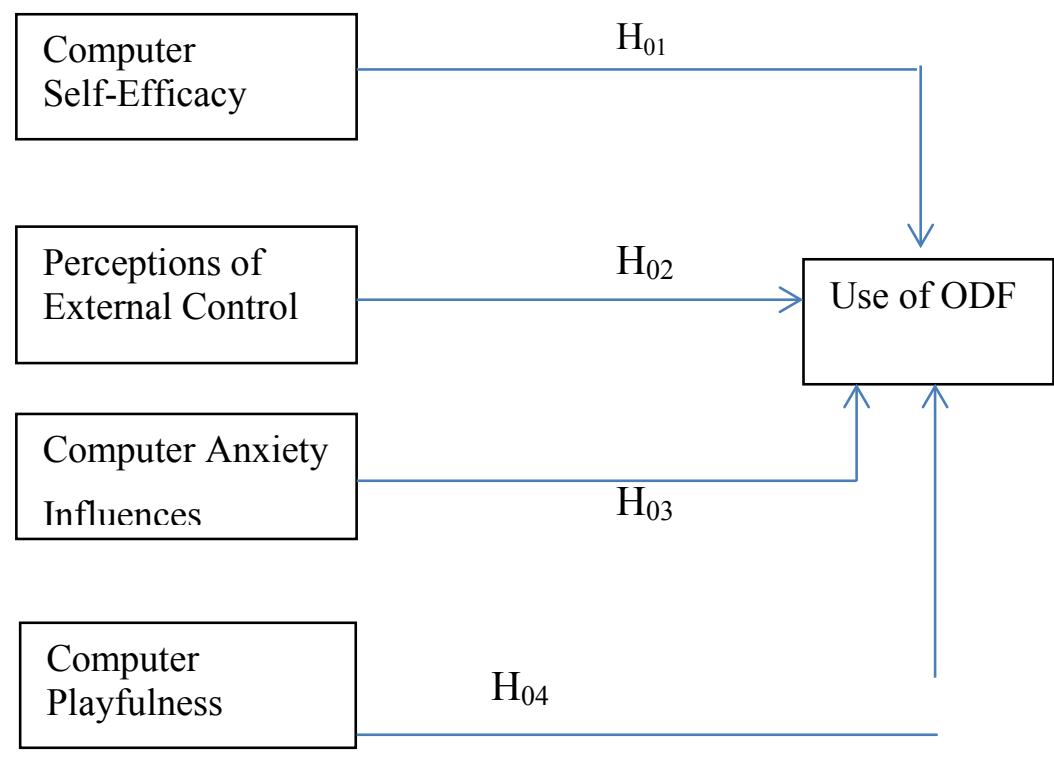

Figure 1: Conceptual Framework Adapted from TAM3

\section{Methodology}

The survey research design was adopted for this study. The population consisted of 121 LIS masters' students taking a collection management course for the academic session. The questionnaire was sent to students on the online discussion forum hosted on the Google group. The research was conducted between May 9 - 16, 2014. The variable used to evaluate TAM 3 included: computer self-efficacy, perceptions of external control, computer anxiety and computer playfulness. Each of the variables contained questions adapted from Peslak et al. (2011). The data was analyzed using descriptive statistics and Pearson's Product Moment Correlation.

\section{Results}

Only seventy six copies of the questionnaire were found useful for analysis. The result revealed that the respondents used ODFs mostly for academic information (51.3\%) and general knowledge $(48.7 \%)$ on a daily basis. This could be because current and relevant information were available on the forum which was easily accessible to the respondents for use to increase their knowledge in collection management. This supports the findings of Cheng, Paré, Collimore, and Joordens (2011) and Goode (2009) who reported that online forum were presently being used globally for graduate education. The percentage of the respondents that never used ODF for any purpose varied from $2.6-10.5 \%$ (Table 1). This is not unexpected as not all respondents will embrace technology at the same time. There are innovators, early adopters, majority adopters, late majority and laggards (Diffusion of Innovation theory by Rogers, 2003). Those that did not use the ODF could be categorized as laggards (16\%) who represent the last group of adopters in the Diffusion of Innovation curve. 
Table 1. Frequency of Using ODFs

\begin{tabular}{|c|c|c|c|c|c|c|c|c|c|c|c|c|}
\hline \multirow[t]{2}{*}{ Purpose } & \multicolumn{2}{|c|}{ Daily } & $\begin{array}{l}\text { Twice a } \\
\text { week }\end{array}$ & $\begin{array}{l}\text { Once a } \\
\text { week }\end{array}$ & \multicolumn{2}{|c|}{$\begin{array}{l}\text { Twice a } \\
\text { month }\end{array}$} & \multicolumn{2}{|c|}{$\begin{array}{l}\text { Once a } \\
\text { Month }\end{array}$} & \multicolumn{2}{|c|}{ Rarely } & \multicolumn{2}{|c|}{ Never } \\
\hline & $\mathrm{N}$ & $\%$ & N \% & N \% & $\mathrm{N}$ & $\%$ & $\mathrm{~N}$ & $\%$ & $\mathrm{~N}$ & $\%$ & $\mathrm{~N}$ & $\%$ \\
\hline Academic Information & 39 & 51.3 & 1114.5 & 911.8 & 6 & 7.9 & 1 & 1.3 & 8 & 10.5 & 2 & 2.6 \\
\hline Professional & 20 & 26.3 & $9 \quad 1.8$ & 67.9 & 5 & 6.6 & 4 & 5.3 & 20 & 26.3 & 12 & 5.8 \\
\hline Notices & 22 & 28.9 & 1215.8 & 1519.7 & 3 & 3.9 & 4 & 5.3 & 13 & 17.1 & 7 & 9.2 \\
\hline Seminar papers & 5 & 6.6 & $\begin{array}{ll}8 & 10.5\end{array}$ & 1418.4 & 4 & 5 & 9 & 11.8 & 28 & 36.8 & 8 & 10.5 \\
\hline News & 35 & 44.9 & 11.5 & 1012.8 & 3 & 3.8 & 1 & 1.3 & 12 & 15.4 & 6 & 7.7 \\
\hline Discussion & 31 & 40.8 & $15 \quad 19.7$ & 911.8 & 5 & 6.6 & 0 & 0.0 & 12 & 15.8 & 4 & 5.3 \\
\hline General Knowledge & 37 & 48.7 & 1114.5 & $9 \quad 11.8$ & 5 & 6.6 & 1 & 1.3 & 8 & 10.5 & 5 & 6.6 \\
\hline
\end{tabular}

\section{Testing of Hypotheses}

$\mathrm{H}_{01}$ There is no significant relationship between LIS Postgraduate Students' Computer Self Efficacy (CSE) and the use of Online Discussion Forums (ODF)

Table 2 reveals that there is a significant relationship between postgraduate students' Computer Self-Efficacy (CSE) and use of Online Discussion Forum $\left(r=.383^{* *}, \mathrm{~N}=76, \mathrm{P}<.01\right)$. The Pearson Correlation Coefficient of 0.383 showed that there is positive significant relationship between postgraduate students' Computer Self Efficacy and use of Online Discussion Forum. The level of significance was at 0.01 .This implies that the extent to which a postgraduate student believes that he or she has the ability to carry out specific task using a computer influences the level of ODF use.

Table 2: Relationship between LIS Postgraduate Students' CSE and Use of ODF

\begin{tabular}{lcccc} 
Variables & Mean & Standard Deviation & N & R \\
$\begin{array}{l}\text { Use of Online Discus- } \\
\text { sion Forum }\end{array}$ & 33.7237 & 10.09237 & 76 & $.383^{* *}$ \\
$\begin{array}{l}\text { Computer Self- Effica- } \\
\text { cy }\end{array}$ & 27.2500 & 4.41550 & 76 & \\
\hline$* * P<0.01$ & & & \\
\hline
\end{tabular}

\section{$H_{02}$ : There is no significant relationship between postgraduate students' perception of Ex-} ternal Control and use of Online Discussion Forum

Table 3 reveals that there was positive relationship between perception of external control (PEC) and use of ODF $(\mathrm{r}=0.271, \mathrm{~N}=76, P<0.01)$. The null hypothesis was therefore rejected and the alternative hypothesis was accepted. The Pearson Correlation Coefficient of 0.271 showed positive correlation between perception of external control and ODF use. 
Table 3: Relationship between LIS Postgraduate Students' Perception of External Control and Use of ODF

\begin{tabular}{lcccc} 
Variables & Mean & Std. Deviation & N & R \\
$\begin{array}{l}\text { Use of Online Discus- } \\
\text { sion Forum }\end{array}$ & 33.7237 & 10.09237 & 76 & $.271^{*}$ \\
$\begin{array}{l}\text { Perception of External } \\
\text { Control }\end{array}$ & 15.9342 & 3.02141 & 76 & \\
\hline$* P<0.05$ & & &
\end{tabular}

$\mathrm{H}_{03}$ : There is no significant relationship between postgraduate students' computer anxiety (CA) and use of Online Discussion Forum

There was significant positive relationship when postgraduate students' computer anxiety was correlated with use of Online Discussion forum $(\mathrm{r}=0.441, \mathrm{~N}=76,<0.05)$. The result in Table 4 indicates that as the computer anxiety of the postgraduate student increases, the use of ODF will reduce.

Table 4: Relationship of LIS Postgraduate Students' Computer Anxiety on Use of ODF

\begin{tabular}{lrrrc} 
Variables & Mean & Std. Deviation & N & R \\
$\begin{array}{l}\text { Use of Online Dis- } \\
\text { cussion Forum }\end{array}$ & 33.7237 & 10.09237 & 76 & $.441^{*}$ \\
Computer Anxiety & 62.5526 & 10.56837 & 76 & \\
\hline$* * P<0.01$ & & & &
\end{tabular}

H04: There is no significant relationship between postgraduate students' Computer Playfulness and use of Online Discussion Forum

Table 5 shows that there is a positive significant relationship between computer playfulness and postgraduate students' use of ODF $(\mathrm{r}=0.351, \mathrm{~N}=76,<0.01)$.

Table 5: Relationship between LIS Postgraduate Students' Computer Playfulness and Use of ODFs

$\begin{array}{lrrrc}\text { Variables } & \text { Mean } & \text { Std. Deviation } & \text { N } & \text { R } \\ \begin{array}{l}\text { Use of Online Dis- } \\ \text { cussion Forum }\end{array} & 33.7237 & 10.09237 & 76 & .351^{* *} \\ \begin{array}{l}\text { Computer Playful- } \\ \text { ness }\end{array} & 12.2763 & 2.89182 & 76 & \end{array}$

$* * P<0.01$ 


\section{Relative effect of anchor factors on LIS postgraduate students' use of online discussion forum}

The anchor factors contributed significantly to postgraduate students' use of Online Discussion Forum (ODF). Table 6 reveals that Computer Anxiety (CAS) made the greatest contribution to the use of ODF by LIS postgraduate students $(\beta=0.441 ;<0.05)$ followed by computer selfefficacy $(\beta=0.383 ;<0.05)$. Perception of external control made the lowest contribution $(\beta=$ $0.271 ;<0.05)$. The findings is supported by Venkatesh $(2000)$, who reported that the anchors factors, that is, computer self-efficacy, perceptions of external control, computer anxiety, and computer playfulness were significant predictors of perceived ease of use of technology.

Table 6: Effect of Anchor Factors on LIS Postgraduate Students' Use of ODF

\begin{tabular}{lccccc}
\multicolumn{1}{c}{ Variable } & Mean & Std. Deviation & $\mathrm{N}$ & $\mathrm{R}$ & Rank \\
Use of ODF (Constant) & 33.7237 & 10.09237 & 76 & & \\
$\begin{array}{l}\text { Computer Self-efficacy } \\
\text { (CSE) }\end{array}$ & 27.2500 & 4.41550 & 76 & $.383^{* *}$ & $2^{\text {nd }}$ \\
$\begin{array}{l}\text { Perception of External } \\
\text { Control (PEC) }\end{array}$ & 15.9342 & 3.02141 & 76 & $.271^{*}$ & $4^{\text {th }}$ \\
$\begin{array}{l}\text { Computer Anxiety (CA) } \\
\text { Computer Playfulness }\end{array}$ & 62.5526 & 10.56837 & 76 & $.441^{* *}$ & $1^{\text {st }}$ \\
$*_{P}<0.05, \quad * * P<0.01$ & 12.2763 & 2.89182 & 76 & $.351^{* *}$ & $3^{\text {rd }}$ \\
\hline
\end{tabular}

\section{Discussion}

This study investigated anchor factors in TAM 3 using acceptance of ODFs by LIS postgraduate students. The anchor factors: computer self-efficacy, perception of external factors, computer anxiety and computer playfulness all had significant influence on use of ODFs by LIS postgraduate students. This is in accordance with Ventakesh (2000) and Venkatesh, \& Bala (2008) who found that the anchor factors are important in deciding to use any new information system. Computer self-efficacy was found to significantly affect the use of ODFs by postgraduate students. The implication is that once a postgraduate student believes he can confidently use a computer, he is likely to use ODFs for learning. The higher the computer self-efficacy of the postgraduate students, the greater the increase in their use of ODFs for learning. This result is supported by Dulle, Minishi-Majanja, and Cloete (2010) who found that internet self-efficacy determined the use of open access for scholarly communication in Tanzanian universities.

The result indicating a positive relationship between perception of external factors and use of ODFs implied that in Nigeria which is a developing country, the increased use of ODFs by postgraduate students will be achieved when the external factors such as internet connectivity and bandwidth, power supply is improved upon. This corresponds with the result of Miller and Khera (2010) who reported that infrastructure and librarian assistance were vital to the acceptance of TEEAL by library users in Kenya and Peru.

Computer anxiety has a significant relationship with the use of ODFs by postgraduate students. The implication of this result is that the higher the computer anxiety displayed by the postgraduate students, the lower their use of ODFs. This result is supported by Alenezi, Abdul Karim, and Veloo (2010) who reported that computer anxiety negatively and significantly influenced stu- 
dents' intention to use E-learning in five Saudi Arabian universities. The relationship between computer playfulness and use of ODFs was found to be significant. This is supported by Lin et. al. (2005) who reported that computer playfulness was a determinant to the use of a website by undergraduates in three Taiwan universities.

All the anchor factors except computer anxiety had positive relationship on use of ODFs by the postgraduate students. This infers that as computer self-efficacy, perception of external conditions and computer playfulness increases, there would be also increase in their use of ODFs for learning by the postgraduate students. However, the higher the computer anxiety of the postgraduate students, the lower their use of ODFs. This is expected, because when there is a fear for the use of computer, it will be apparent that they would not use ODFs even with its many benefits for learning.

\section{Conclusion and Recommendations}

The use of technology for learning is increasingly accepted in Nigerian universities. Postgraduate students embrace online discussion forums (ODFs) to promote learning. Anchor factors in TAM 3 were used to analyse the use of ODFs by the postgraduate students and were found to be determinants of use of ODFs. For increased and improved use of ODFs for learning, it is essential to consider among other factors: computer self-efficacy, perception of external conditions, computer anxiety and computer playfulness of postgraduate students. The institution and instructor must provide an enabling environment and also consider the behavior of the postgraduate students to promote e-learning using online discussion forum. Alternate models such as Unified Theory of Use and Acceptance of Technology (UTUAT) and Social Presence (SPM) could be used to examine the use of Online Discussion Forums for learning.

\section{References}

Adams, D. A., Nelson, R.R. \& Todd, P.A. (1992). Perceived usefulness, ease of use, and usage of information technology: A replication. MIS Quarterly, 16(2), 227-247.

Agarwal, R.,\& Karahanna, E. (2000). Time flies when you're having fun: Cognitive absorption and beliefs about information technology usage. MIS Quarterly, 24, 665-694.

Aggorowati, M. A., Iriawan, N., Suhartono, \& Gautama, H. (2012). Restructuring and Expanding Technology Acceptance Model Structural Equation Model and Bayesian Approach. American Journal of Applied Sciences, 9 (4), 496-504.

Al-adwan, A. and Smedley, J. (2012). Implementing e-learning in the Jordanian Higher Education System: Factors affecting impact. International Journal of Education and Development using Information and Communication Technology (IJEDICT), 8(1),121-135.

Alenezi, A.R.; Abdul Karim, A. \& Veloo, A. (2010). An empirical investigation into the role of enjoyment, computer anxiety, computer self-efficacy and internet experience in influencing the students' intention to use of e-learning: A case study from Saudi-Arabian Government Universities. The Turkish Online Journal of Educational Technology, 9(4), 22-34.

Attuquayefio, S. N. and Addo, H. (2014). Using the UTAUT model to analyze students' ICT adoption. International Journal of Education and Development using Information and Communication Technology (IJEDICT), 10(3), 75-86.

Bagozzi, R.P. (2007). The legacy of the technology acceptance model and a proposal for a paradigm shift. Journal of the Association for Information Systems, 8 (4), 244-254.

Balaji, M. S.\& Chakrabarti, D. (2010). Student Interactions in Online Discussion Forum: Empirical Research from 'Media Richness Theory' Perspective. Journal of Interactive Online Learning, 9(1), Retrieved July 20, 2014, from http://www.ncolr.org/jiol/issues/pdf/9.1.1.pdf 
Blackmon, S. (2012). Outcomes of Chat and Discussion Board Use in Online Learning: A research synthesis. Journal of Educators Online, 9(1). Retrieved March 2, 2015, from http://www.thejeo.com/Archives/Volume9Number2/BlackmonPaper.pdf.

Bonk, C.J.; Kim, K-J. and Zeng, T. (2006). Future directions of blended learning in higher education and workplace learning settings In C. Bonk \& C. Graham (Eds.), The handbook of blended learning: Global perspectives local designs (pp. 550-567). San Francisco: Pfeiffer. Retrieved March 2, 2015, from http://www.publicationshare.com/c083_bonk_future.pdf

Cheng, C.K, Paré, D. E., Collimore, L.-M., Joordens, S. (2011).Assessing the effectiveness of a voluntary online discussion forum on improving students' course performance. Computers and Education, 56(1), 253-261.

Compeau, D. R., \& Higgins, C. A. (1995a). Application of social cognitive theory to training for computer skills. Information Systems Research, 6, 118-143.

Compeau, D. R., \& Higgins, C. A. (1995b). Computer self-efficacy: Development of a measure and initial test. MIS Quarterly, 19, 189-211.

Davis, F.D. (1989). Perceived usefulness, perceived ease of use and user acceptance of information technology. MIS Quarterly, 13(3), 319-339.

Davis, F.D., Bagozzi, R.P., \& Warshaw, P.R. (1989). User acceptance of computer technology: a comparison of two theoretical models. Management Science, 35(8), 982-1003.

Davis, F.D., Bagozzi, R.P., \& Warshaw, P.R. (1992). Extrinsic and intrinsic motivation to use computers in the workplace. Journal of Applied Social Psychology, 22, 1111-1131.

Davis, F. D., \& Venkatesh, V. (2004). Toward preprototype user acceptance testing of new information systems: Implications for software project management. IEEE Transactions on Engineering Management, 51(1), 31-46.

Dorman, J. P., \& Fraser, B. J. (2009). Psychosocial environment and affective outcomes in technology-rich classrooms: Testing a causal model. Social Psychology of Education, 12(1), 77-99.

Dulle, F.W., Minishi-Majanja, M.K. \& Cloete, L.M. (2010). Factors influencing the adoption of open access scholarly communication in Tanzanian public universities. World Library and Information Congress: $76^{\text {th }}$ IFLA General Conference and Assembly 10-15, August. Retrieved May 8, 2014, from http://conference.ifla.org/drupa/past-wlic/2010/138-dulle-en.pdf.

Gong, M. Xu, Y. and Yu, Y. (2004). An enhanced technology acceptance model for web-based learning. Journal of Information Systems Education, 15(4), 365-374.

Goode, M. (2009). Implementation of Online Forums in Graduate Education. Presentado en II ACE Seminar: Knowledge Construction in Online Collaborative Learning Communities, XVII ISTEC General Assembly. Albuquerque, New Mexico. October, 2009.

Havard, B, Du, J \& Olinzock, A 2005, 'Deep Learning: The Knowledge, Methods, and Cognition Process in Instructor-led Online Discussion', Quarterly Review of Distance Education, 6(2), 125-35.

Hendrickson, A. R., Massey, P. D., \& Cronan, T. P. (1993). On the test-retest reliability of perceived usefulness and perceived ease of use scales. MIS Quarterly, 17, 227-230.

Hu, P.J., Chau, P.Y.K., Sheng, O.R.L., \& Tam, K.Y. (1999). Examining the technology acceptance model using physical acceptance of telemedicine technology. Journal of Management Information Systems, 16(2), 91-112.

Karahanna, E., \& Straub, D. W. (1999). The psychological origins of perceived usefulness and ease of use. Information and Management, 35, 237-250.

Karahanna, E., Straub, D. W., \& Chervany, N. L. (1999). Information technology adoption across time: Across-sectional comparison of pre-adoption and post adoption beliefs. MIS Quarterly, 23, 183-213. 


\section{Online Discussion Forums}

Karahanna, E., Agarwal, R., \& Angst, C. M. (2006). Reconceptualizing compatibility beliefs in technology acceptance research. MIS Quarterly, 30, 781-804.

King, W. R. and He, J. (2006). A meta-analysis of the technology acceptance model. Information Management, 43, 740-755.

Koufaris, M. (2002). Applying the technology acceptance model and flow theory to online consumer behavior. Information Systems Research, 13, 205-223.

Lee, Y., Kozar, K.A. \& Larsen, K.R.T. (2003). The Technology Acceptance Model: Past, Present, and the Future. Communications of Association for Information Systems, 12(50), 752-780.

Lyons, T. and Evans, M.M. (2013). Blended Learning to Increase Student Satisfaction: An Exploratory Study. Internet Reference Services Quarterly, 18(1), 43-53

Masrom, M. (2007). Technology Acceptance Model and E-Learning. 12th International Conference on Education, Sultan Hassanal Bolkiah Institute of Education, Universiti Brunei Darussalam 21-24 May 2007.

Mathieson, K. (1991). Predicting user intentions: comparing the technology acceptance model with theory of planned behavior. Information Systems Research, 2(3), 173-191.

Miller, J. and Khera, O. (2010). Digital Library Adoption and the Technology Acceptance Model: A cross country analysis. The Electronic Journal on Information Systems in Developing Countries, 40(6), 1-19.

Pena-Shaff, J. B., \& Nicholls, C. (2004). Analyzing student interactions and meaning construction in computer bulletin board discussions. Computers \& Education, 42(3), 243-265.

Redmon, R., \& Burger, M. (2004). Web CT discussion forums: Asynchronous group reflection of the student teaching experience'. Curriculum and Teaching Dialogue, 6(2), 157-166.

Rogers, E.M. (2003). Diffusion of innovations (5th ed.). New York: Free Press.

Saade, R. G. and Kira, D. (2009). Computer anxiety in e-learning: The effect of computer, self-efficacy. Journal of Information Technology Education, 8, 177-191.

Struyven, K., Dochy, F., Janssens, S., \& Gielen, S. (2006). On the dynamics of students' approaches to learning: The effects of the teaching/learning environment. Learning and Instruction, 16(4), 279-294.

Van Der Heijden, H. (2004). User acceptance of hedonic information systems. MIS Quarterly, 28, 695705.

Venkatesh, V. (2000). Determinants of perceived ease of use: Integrating perceived behavioural control, computer anxiety and enjoyment into the Technology Acceptance Model. Information Systems Research, 11, 342-365.

Venkatesh, V., \& Bala, H. (2008). Technology Acceptance Model 3: Research Agenda on interventions. Decision Sciences, 39(2), 273-315.

Venkatesh, V., Davis, F. D., \& Morris, M. G. (2007). Dead or alive? The development, trajectory and future of technology adoption research. Journal of the Association for Information Systems, 8, 267-286.

Venkatesh, V., \& Morris, M. G. (2000). Why don't men ever stop to ask for directions? Gender, social influence, and their role in technology acceptance and usage behavior. MIS Quarterly, 24, 115-139.

Venkatesh, V., Morris, M. G., Davis, G. B., \& Davis, F. D. (2003). User acceptance of information technology: Toward a unified view. MIS Quarterly, 27, 425-478.

Warren, C. (2008). The Use of Online Asynchronous Discussion Forums in the development of Deep Learning among Postgraduates Real Estate Students. CIB International Conference on Building Education and Research, Sri Lanka, 11-15 February 2008.

Whiteside, A. L. (2007). Exploring Social Presence in Communities of Practice within a Hybrid Learning Environment: A Longitudinal Examination of Two Case Studies within the School Technology Leadership Graduate-Level Certificate program, Dissertation, Department of Writing Studies, University of 
Minnesota. Retrieved March 2, 2015, from

http://books.google.com.ng/books?id=uf1DJvZUZC4C\&printsec=frontcover\&dq=isbn:0549153233

Yukselturk, E. (2010). An investigation of factors affecting student participation level in an online discussion forum. TOJET: The Turkish Online Journal of Educational Technology, 9(2). Retrieved March 4, 2015, from http://www.tojet.net/articles/v9i2/923.pdf

\section{Biography}

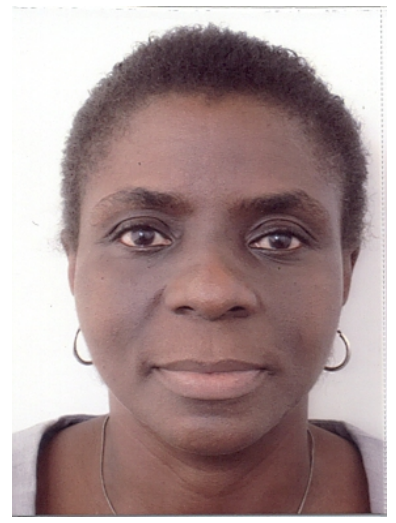

Airen Adetimirin is a lecturer in the Department of Library, Archival and Information Studies, University of Ibadan, Nigeria since 2005 and teaches undergraduate and postgraduate courses related to the use of Information and Communication Technology (ICT) in library and information science profession. She has a Bachelor degree in Agriculture (Crop Science), Master of Library Studies and Ph.D in Library Studies from the University of Ibadan, Nigeria and certificates on virtual instruction from University of Irvine, California, USA and Coursera. Airen's research focus is on use of ICT for e-learning, library service delivery, teaching, literacy and distance learning. 